\title{
COMPARISION BETWEEN THE MOST COMMON MECHANICAL METHODS AND RICE COMBEIN MODIFIED FOR HARVESTING WHEAT CROP IN THE EGYPTAIN FIELDS
}

\author{
SHREEN F.A.M., M.E. BADAWY and M.H. M. ABO EL-NAGA
}

Agricultural Engineering Research Institute, ARC, Giza, Egypt.

(Manuscript received 18 March 2014)

\begin{abstract}
Used modified rice combine for cutting wheat crops to maximize utilization of it. Five wheat harvesting systems were evaluated at three average grain moisture contents of $\left(\mathrm{MC}_{1}=20.80, \mathrm{MC}_{2}=18.50\right.$ and $\mathrm{MC}_{3}$ $=16.65 \%$ ) namely: traditional harvesting (Hand cutting), partial mechanization (modified combine harvester, self-propelled reaper binder, self- propelled vertical conveyor reaper and tractor mounted vertical conveyor reaper windrower).

The experiments were carried out in wheat fields to determine total grain losses, energy consumed and cost requirements for harvesting wheat crop. The results indicated that, traditional harvesting system gave the lowest values of grain loss by average 2.00, 2.92 and $2.34 \%$ under moisture contents of $20.80,18.50$ and $16.65 \%$, respectively. The highest value of cutting efficiency $97.2 \%$ was notice under used combine machine with forward speed of $1.5 \mathrm{~km} / \mathrm{h}$ and moisture content of $16.65 \%$. The minimum cost requirements values were obtained by using self-propelled reaper binder of $17.17,15.2014 .00$, L.E/fed at the higher forward speed of $3.3 \mathrm{~km} / \mathrm{h}$ under different grain moisture contents of 20.80, 18.50 and $16.65 \%$, respectively. While the maximum cost requirements was obtained by using modified combine of $73.96,72.8$ and $70.71 \mathrm{~L} . \mathrm{E} / \mathrm{fed}$ at the lower forward speed of $1.5 \mathrm{~km} / \mathrm{h}$ under different grain moisture contents of $20.80,18.50$ and $16.65 \%$, respectively.
\end{abstract}

\section{INTRODUCTION}

Wheat crop is considered one of the most strategic important foods and economical crops in Egypt. Whereas, wheat crop harvesting machines have a great effect on the crop losses in field. Fouad et al. (1990) compared the performance of two types of combines in harvesting rice crop in Egypt. The combines were operated at three forward speeds of $0.9,2.3$ and $2.8 \mathrm{~km} / \mathrm{h}$ for rice combine, and $0.8,2.1$ and $2.9 \mathrm{~km} / \mathrm{h}$ for the conventional combine. There was a highly significant decrease in total harvesting costs with an increase in operation speed from 0.9 and $0.8 \mathrm{~km} / \mathrm{h}$ to 2.3 and $2.2 \mathrm{~km} / \mathrm{h}$ for the rice and conventional combines, respectively. Hassan et al. (1994) experimentally investigated the performance of combine device during harvesting operation of both wheat and rice crops. The experimental results revealed that the total grain losses and criterion cost were minimum value, while the performance efficiency was maximizing under following conditions: 
- Forward speed of $2.1 \mathrm{~km} / \mathrm{h}$ for rice and $2.8 \mathrm{~km} / \mathrm{h}$ for wheat.

- Cutter bar speed of $1.2 \mathrm{~m} / \mathrm{s}$ for both rice and wheat crops.

- Cylinder speed of $25 \mathrm{~m} / \mathrm{s}$ for rice crop and $30 \mathrm{~m} / \mathrm{s}$ for wheat crop.

- Concave clearance of $9.0 \mathrm{~mm}$ for rice crop and $12.0 \mathrm{~mm}$ for wheat crop.

- Grain moisture content of $22.30 \%$ and $19.20 \%$ for rice and wheat crops.

El-Haddad et al. (1995) reported that combine harvester gave the lowest cost of about 229.0 L.E/fed in comparison with 283.4 L.E/fed for mounted mower and 300.0 L.E/fed for manual sickle system. EL-Sayed et al. (2002) found that increasing forward speed from 1.7 to $2.7 \mathrm{~km} / \mathrm{h}$ the harvesting unthreshed losses total losses and field capacity increased from 1.3, 1.1, $5.5 \%, 1.1 \mathrm{fed}, / \mathrm{h}$ to $1.0,2.4,5.4 \%, 1.4 \mathrm{fed}, / \mathrm{h}$, respectively and the damaged losses, performance efficiency decreased from 1.2, and $94.5 \%$ to 0.86 and $94.0 \%$, respectively. Too, at using wheat header in harvesting decreased total losses and criterion cost from 27, $15 \%$ and 824 L.E / ton to $8.75 \%$ and 344 L.E/ton respectively. Also, the performance efficiency from $77.72 \%$ to 92.82 $\%$ than using the corn header combines. Imara et al. (2003) found that the total grain wheat losses increased by increasing the combine forward speed. The total grain losses of indirect harvesting method (using mower and threshing machine) increased about 2.5 times of that of total grain losses of direct harvesting (using combine). Abo EL- Naga et al. (2010) evaluated the performance of locally combine for harvesting wheat crops. they found that the highest cutting efficiency of $94.81 \%$ was obtained at forward speed of $0.53 \mathrm{~km} / \mathrm{h}$ and grain moisture content of $12.13 \%$. The highest effective field capacity and efficiency ( $0.48 \mathrm{fed} / \mathrm{h}$ and $78.38 \%$ ) were obtained at forward speed of (1.15 and $0.53 \mathrm{~km} / \mathrm{h}$ ) and grain moisture content of $12.13 \%$, respectively. Whereas the lowest value of energy requirements of $311.01 \mathrm{~kW} . \mathrm{h} / \mathrm{fed}$ was at forward speed of $1.15 \mathrm{~km} / \mathrm{h}$ and grain moisture content of $12.13 \%$, respectively. The lowest value of criterion cost of 312.10 L.E / fed was obtained at forward speed of $1.15 \mathrm{~km} / \mathrm{h}$ and grain moisture content of $12.13 \%$. El-Yamani(2013) used a developed combine harvester type of crop tiger (after modification) to study the effect of forward speed of $1.67,1.92,2.33$ and $2.64 \mathrm{~km} / \mathrm{h}$, drum speed of 18.85, 22.94 and 27.13 and $32.27 \mathrm{~m} / \mathrm{s}$, concave clearance of $9.5 / 4.5,11.5 / 5.5,13 / 6$ and $18 / 8$ $\mathrm{mm}$ and seeds moisture content of $10.3,7.9$ and $5.4 \%$ for seeds $(17.8,13.2$ and $10.6 \%$ for straw) at harvesting Egyptian clover seeds on effective field capacity and field efficiency, combine productivity, header losses, total grain losses contain (unthreshed seed losses, threshed seed losses and cleaning losses), total seed damage contain (visible and invisible). Also, determination of specific fuel consumption, operating cost and criterion function cost of Egyptian clover harvesting were done. Results indicated that, the maximum of $1.15 \mathrm{fed} / \mathrm{h}$ field capacity and 
$83.1 \%$ field efficiency were recorded. Also, the maximum field productivity was 0.805 ton/fed and a minimum of header losses was $0.83 \%$. On the other hand, a minimum of visible damage, invisible damage, total damage and total losses were $0.48,1.61$, 1.09 and $2.44 \%$ also minimum specific fuel consumption and cost harvest were 0.276 I/kW.h and 83.4 L.E/fed respectively. Finally, the performance characteristics of machine were influenced by the investigated variables.

The aim of the present study is to compare between the more common harvesting machines in Egyptian field wheat to harvest crop and determine the strength and weak points by using different machines.

\section{MATERIALS AND METHODS}

Field experiments were carried out on wheat crop at a private farm in Elsharkia governorate during the agricultural summer season 2013. The total experimental area was about 5.5 feddans planted with wheat (Maser-1) crop. This study carried out to determine total grain losses, energy consumed and total cost required by using four different mechanical systems and traditional method for harvest wheat crop, to stand up the optimum method which suitable for harvesting wheat under Egyptian conditions.

\section{Materials:}

Table.1 indicated the technical specifications of machines which used in this study.

Table 1. Technical specifications of the used machines

\begin{tabular}{|c|c|c|c|c|}
\hline $\begin{array}{l}\text { Specification of } \\
\text { machines }\end{array}$ & $\begin{array}{l}\text { Modified combine } \\
\text { for harvesting } \\
\text { (Kubota) }\end{array}$ & $\begin{array}{l}\text { Self-propelled } \\
\text { reaper binder }\end{array}$ & $\begin{array}{l}\text { Self- propelled } \\
\text { vertical } \\
\text { conveyor } \\
\text { reaper }\end{array}$ & $\begin{array}{l}\text { Tractor mounted } \\
\text { vertical conveyor } \\
\text { reaper windrower }\end{array}$ \\
\hline Type & CA-385 EG Japan & AR 120 & Local & Local \\
\hline Model & $\begin{array}{l}\text { Turbo diesel, } 4 \\
\text { stroke, } \quad \text { water } \\
\text { cooled, } 3 \text { cylinder }\end{array}$ & $\begin{array}{l}\text { GS } 130-2 \text { CN } \\
\text { Air-cooled, Diesel } \\
\text { engine }\end{array}$ & $\begin{array}{l}\text { Local factor } \\
\text { Air-cooled, } \\
\text { Diesel engine }\end{array}$ & $\begin{array}{l}\text { Tractor, } \\
\text { Romania. } \\
\text { Engine type Four } \\
\text { stroke diesel }\end{array}$ \\
\hline $\begin{array}{l}\text { Dimensions, } \quad \mathrm{mm} \\
(\mathrm{LxW} \times \mathrm{H})\end{array}$ & $4065 \times 1905 \times 2000$ & $\begin{array}{l}2300 \times 1450 \times \\
1000\end{array}$ & $\begin{array}{l}: 2450 \times 1200 \times \\
1000\end{array}$ & $1800 \times 90 \times 60$ \\
\hline Mass, $\mathrm{kg}$ & 1980 & 110 & 145 & 165 \\
\hline Working width, mm & 1600 & 1200 & 1000 & 1600 \\
\hline Engine power, $\mathrm{hp}$ & 90 & 10.5 & 3 & 35 \\
\hline Revolution speed, rpm & 2700 & 1800 & 1200 & 1440 \\
\hline
\end{tabular}

\section{Modified combine harvester:}

To maximize utilization of rice combine by modifying the machine for cutting only. The combine harvest machine was modified to cut crop only instead of combination 
processes. The motion was transmitted from power source to cutter bar and separated it about the parts residual. A plate was put in the end of cutter bar to throw the crop beside the machine, it was shown in Fig. (1).

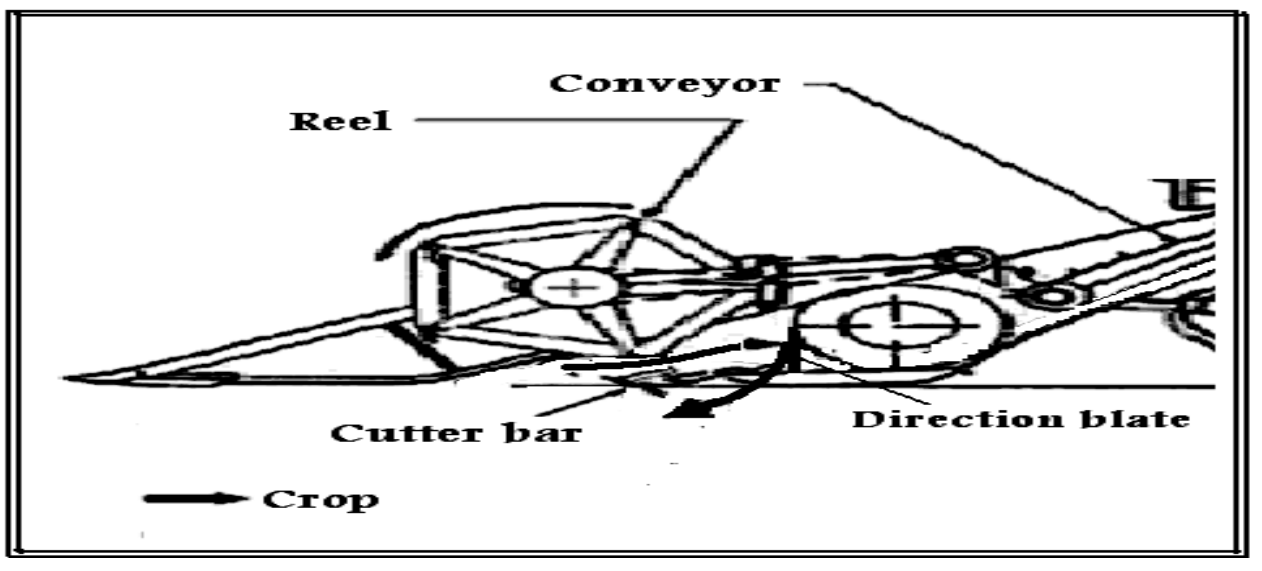

Fig. 1: The layout of modify part of combine machine.

\section{Some wheat crop characteristics:}

Some wheat crop characteristics are included in Table 2.

Table 2. Mean values of some characteristics of wheat crop variety (Maser-1).

\begin{tabular}{|l|l|}
\hline Characteristics & Mean values \\
\hline Mean plant height $(\mathrm{cm})$ & 99.64 \\
\hline Mean thousand grain mass $(\mathrm{g})$ & 43.86 \\
\hline Spike grain mass $(\mathrm{g})$ & 2.17 \\
\hline No of grain /spike & 53.42 \\
\hline No of spikes / $\mathrm{m}^{2}$ & 395.35 \\
\hline
\end{tabular}

\section{Treatments and experimental design:}

The plot design pertinently was used moisture content the main factor and forward speed the secondary factor, it was shown in Table 3.

Table 3. The distribution of treatments in field.

\begin{tabular}{|c|c|c|c|c|c|c|c|c|c|c|c|c|}
\hline \multirow[b]{2}{*}{ t. } & \multicolumn{3}{|c|}{$\begin{array}{l}\text { Modified } \\
\text { harvester }\end{array}$} & \multicolumn{3}{|c|}{$\begin{array}{l}\text { Self-propelled reaper } \\
\text { binder }\end{array}$} & \multicolumn{3}{|c|}{$\begin{array}{l}\text { Self- } \\
\text { vertical } \\
\text { reaper }\end{array}$} & \multicolumn{3}{|c|}{$\begin{array}{l}\text { Tractor mounted } \\
\text { vertical conveyor } \\
\text { reaper windrower }\end{array}$} \\
\hline & $\mathrm{MC}_{1}$ & $\mathrm{MC}_{2}$ & $\mathrm{MC}_{3}$ & $M C_{1}$ & $\mathrm{MC}_{2}$ & $\mathrm{MC}_{3}$ & $M C_{1}$ & $\mathrm{MC}_{2}$ & $\mathrm{MC}_{3}$ & $\mathrm{MC}_{1}$ & $\mathrm{MC}_{2}$ & $\mathrm{MC}_{3}$ \\
\hline \multicolumn{13}{|l|}{$\mathrm{S}_{1}$} \\
\hline \multicolumn{13}{|l|}{$\mathrm{S}_{2}$} \\
\hline $\mathrm{S}_{3}$ & & & & & & & & & & & & \\
\hline
\end{tabular}

$\mathrm{S}=$ forward speed, $\mathrm{MC}=$ moisture content $\left(\mathrm{MC}_{1}=20.80, \mathrm{MC}_{2}=18.50\right.$ and $\left.\mathrm{MC}_{3}=16.65 \%\right)$. The number of plots was three for hand cutting and 36 plots for mechanical harvesting, the plot dimension was $12 \times 49 \mathrm{~m}$. 


\section{Methods:}

In this study, five harvesting systems were evaluated in wheat fields at three average grain moisture contents of $\left(\mathrm{MC}_{1}=20.80, \mathrm{MC}_{2}=18.50\right.$ and $\left.\mathrm{MC}_{3}=16.65 \%\right)$ namely:

1- Traditional harvesting (Hand cutting).

2- Mechanical harvesting machines (Modified combine harvester, Self-propelled reaper binder, Self- propelled vertical conveyor reaper and tractor mounted vertical conveyor reaper windrower).

In traditional harvesting, 10 workers harvested the experimental ( 5 fed) area using manual sickles. The forward speed were $(2.0,2.8$ and $3.3 \mathrm{~km} / \mathrm{h})$ for self-propelled reaper binder and tractor mounted vertical conveyor reaper windrower and for selfpropelled vertical conveyor reaper and combine were $(0.1,1.3$ and $1.5 \mathrm{~km} / \mathrm{h})$ and $(1.5$, 2.1 and $2.7 \mathrm{~km} / \mathrm{h}$ ) respectively.

\section{Grain moisture content:}

For each treatment, a random grains sample was taken, to determine the moisture content by using apparatus electronic moisture meter( GANN Hydromelle G 86), Made in Western Germany with accurate 0.05 .

\section{Total grain losses:}

\section{Pre-harvest losses.}

Pre-harvesting losses were determined by using a wooden frame at dimension of $1 \times 1 \mathrm{~m}$, it was put randomized through stand crop before harvesting to collect and weight of the grains from the inside it, this case replicated ten times and the percentage of pre-harvest losses was calculated by using the following equation,

Pre-harvest losses, $\%=\frac{\text { Mass of collected grains, } \mathrm{kg}}{\text { Total mass of grains, } \mathrm{kg}} \times 100$

\section{Cutting losses:}

After harvesting process, the wooden frame was put on the surface land in the harvested area, and collected (seeds, uncut and kernel seeds). The percentage of total grain losses were calculated by using the following equation:

$$
\begin{aligned}
& \text { Cutting losses, } \%= \\
& \frac{[(\text { seeds }+ \text { un }- \text { cut }+ \text { ker nelseeds }) \text { losses }- \text { preharvestlosses }] / \text { fed }}{\text { totalyield } / \text { fed }} \times 100
\end{aligned}
$$

\section{Cutting efficiency:}

The cutting efficiency $\left(E_{c} \%\right)$ was calculated by using the following equation, 


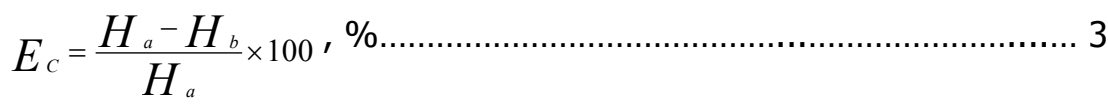

Where,

$\mathrm{H}_{\mathrm{a}}=$ height of stand plant above the soil surface before cutting, $\mathrm{cm}$. and

$\mathrm{H}_{\mathrm{b}}=$ height of the stubble after cutting, $\mathrm{cm}$.

\section{The field capacity and field efficiency:}

\section{Theoretical field capacity}

The theoretical field capacity was determined as the following.

$F_{t h}=\frac{S \times W}{4200}$

Where:

$\mathrm{F}_{\mathrm{th}}=$ theoretical field capacity, fed/h, $\mathrm{S}=$ forward speed, $\mathrm{m} / \mathrm{h}$. , and $\mathrm{W}=$ cutter bar width, $\mathrm{m}$.

\section{The actual field capacity:}

The actual field capacity was calculated as follows Abd EL-Aal, et al., 2002.

$F_{a c t}=\frac{60}{t_{u}+t_{i}}$

Where:

$F_{a c t}=$ actual field capacity, fed/h, $t_{u}=$ the utilized time $/$ fed, min. and $t_{i}=$ the summation of lost times /fed, min.

Field efficiency $\left(\eta_{f}, \%\right)$ :

The field efficiency was calculated by using the following formula:

$\eta_{f}=\frac{F_{a c t}}{F_{t h}} \times 100$ .6

Where: $\quad F_{t h}=$ Theoretical field capacity, fed $/ \mathrm{h}$.

\section{Energy consumed:}

To estimate the energy consumed during harvesting process, the decrease in fuel level was accurately measured immediately after each treatment. The following formula was used to estimate the engine power. Hunt, 1983.

$E_{P}=\left(F_{C} \times \frac{1}{3600}\right) P E \times L . C . V . \times 427 \times \eta_{t h} \times \eta_{m} \times \frac{1}{75} \times \frac{1}{1.36}$

Solving equation (7) as:-

Engine power (Diesel) $=1.96 . f \mathrm{ckW}$. 8

Engine power (Otto ) $=3.16 . f c k W$. 9

Where:-

f.c $=$ The fuel consumption, $/ / \mathrm{h}$,

$P E \quad=$ The density of fuel, $\mathrm{kg} / /$ (for Gas oil $=0.85$ and Gasoline $=0.72$ ), 
L.C.V = The lower calorific value of fuel, $11.000 \mathrm{k} . \mathrm{cal} / \mathrm{kg}$,

$\eta_{t h}=$ Thermal efficiency of the engine (35\% for Diesel and $25 \%$ for Otto),

$427=$ Thermo-mechanical equivalent, $\mathrm{Kg} \cdot \mathrm{m} / \mathrm{k} \cdot \mathrm{cal}$ and

$\eta_{m} \quad=$ Mechanical efficiency of the engine ( $80 \%$ for Diesel and $85 \%$ for Otto).

Hence, the specific energy consumed can be calculated as follows:-

Consumed energy, $\mathrm{kW} . \mathrm{h} /$ fed. $=\frac{\text { Enginepower }, \mathrm{kW} .}{\text { Feildcapacity }, \mathrm{Fed} / \mathrm{h}}$. 10

\section{Human energy:}

For each operation the consumed human energy $\left(E_{H}\right)$ was estimated based on the power of one laborer, which considered being about $0.1 \mathrm{hp}$.

\section{Harvesting cost:}

The total cost of harvesting operation was estimated using the following equation, Awady 1982:-

Cost requirements, L.E./Fed. $=\frac{\text { Machine } \cos t, L . E / h .}{\text { Actualfieldcapacity, Fed } / h \text {. }}$

Machine cost was determined by using the following equation, Awady 1978:-

$$
C=\frac{p}{h}\left(\frac{1}{a}+\frac{i}{2}+t+r\right)+(0.9 \times w \times S \times F)+\frac{m}{144}
$$

Where:-

$C=$ Hourly cost, L.E/h,

$h=$ Yearly working hours, h/year,

$\mathrm{h}$,

$I=$ Interest rate/year,

$t=$ Taxes, over heads ratio,

$m=$ Monthly average wage, L.E,

$W=$ Engine power, $\mathrm{hp}$,

//hp.h.and

$144=$ Reasonable estimation of monthly working hours.

\section{RESULTS AND DISCUSSION}

In this study, the discussions will cover the effect of harvesting systems as function of machines forward speeds and grain moisture contents on total grain losses, cutting efficiency, field capacity and efficiency, energy consumed and total cost requirements for harvesting wheat crop. Too, description of a crop condition before 
harvest operation was an important factor in a machine performance and has a great effect on loss and final conditions of grain and straw yield.

\section{The effect of crop moisture content and forward speed on grain losses:}

Loss is defined as a measurable decrease of the food quantity and quality, loss should not be confused with harvesting method. Fig.2. Shows the total grain losses during harvesting wheat crop by using traditional harvesting system, so the highest value was $3.2 \%$ at moisture content $16.65 \%$, and the lowest value was $2.4 \%$ at moisture content $20.80 \%$. Add to that the maximum value of total grain losses by using modified combine harvester, self-propelled reaper binder, self- propelled vertical conveyor reaper and tractor mounted vertical conveyor reaper windrower were about 4.72, 5.05, 5.24 and $6.12 \%$ under moisture content of $16.65 \%$, and forward speeds of $2.7,3.3,1.5$ and $3.3 \mathrm{~km} / \mathrm{h}$ respectively. The minimum value of total grain losses during harvesting wheat crop by using modified combine harvester, selfpropelled reaper binder, self- propelled vertical conveyor reaper and tractor mounted vertical conveyor reaper windrower were about 3.52, 3.64, 4.12 and $4.25 \%$ under moisture contents of $20.80 \%$, and forward speed 1.5, 2.0, 1.0 and $2.0 \mathrm{~km} / \mathrm{h}$ respectively(Fig.3). It is worth to mention, that the decrease of grain moisture content leads to increase total grain losses due to more increasing in both pre- harvest losses and cutting losses, which cause more shattering losses by cutter bar consequently combine modified was gave the lowest total grain losses $3.5 \%$. The descently value of harvest methods as tractor mounted vertical conveyor reaper windrower, selfpropelled vertical conveyor reaper, self-propelled reaper binder, combine harvesting system and traditional harvesting system.

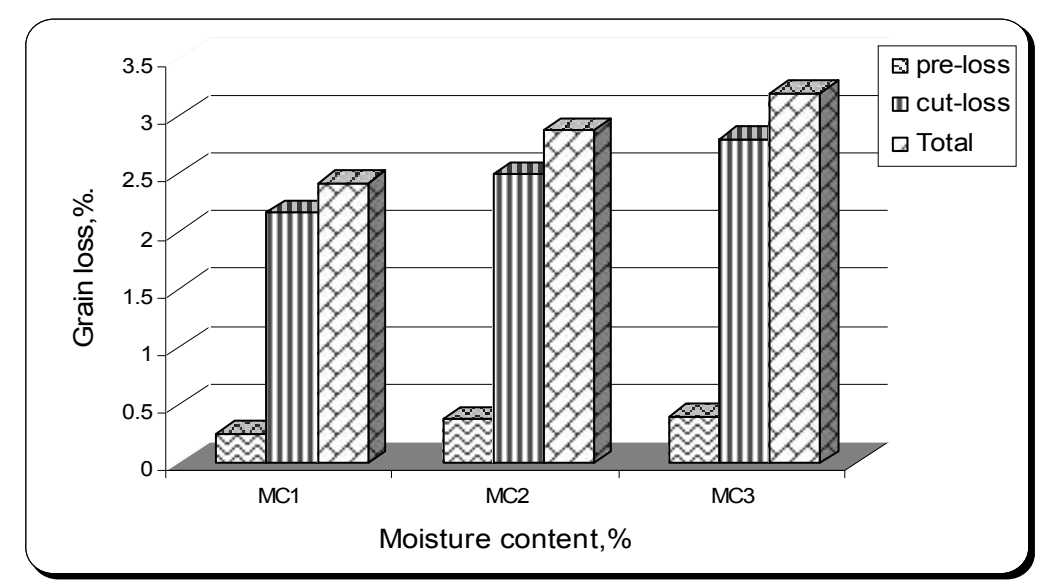

Fig.2. Effect of moisture content on grain losses by using traditional method. 

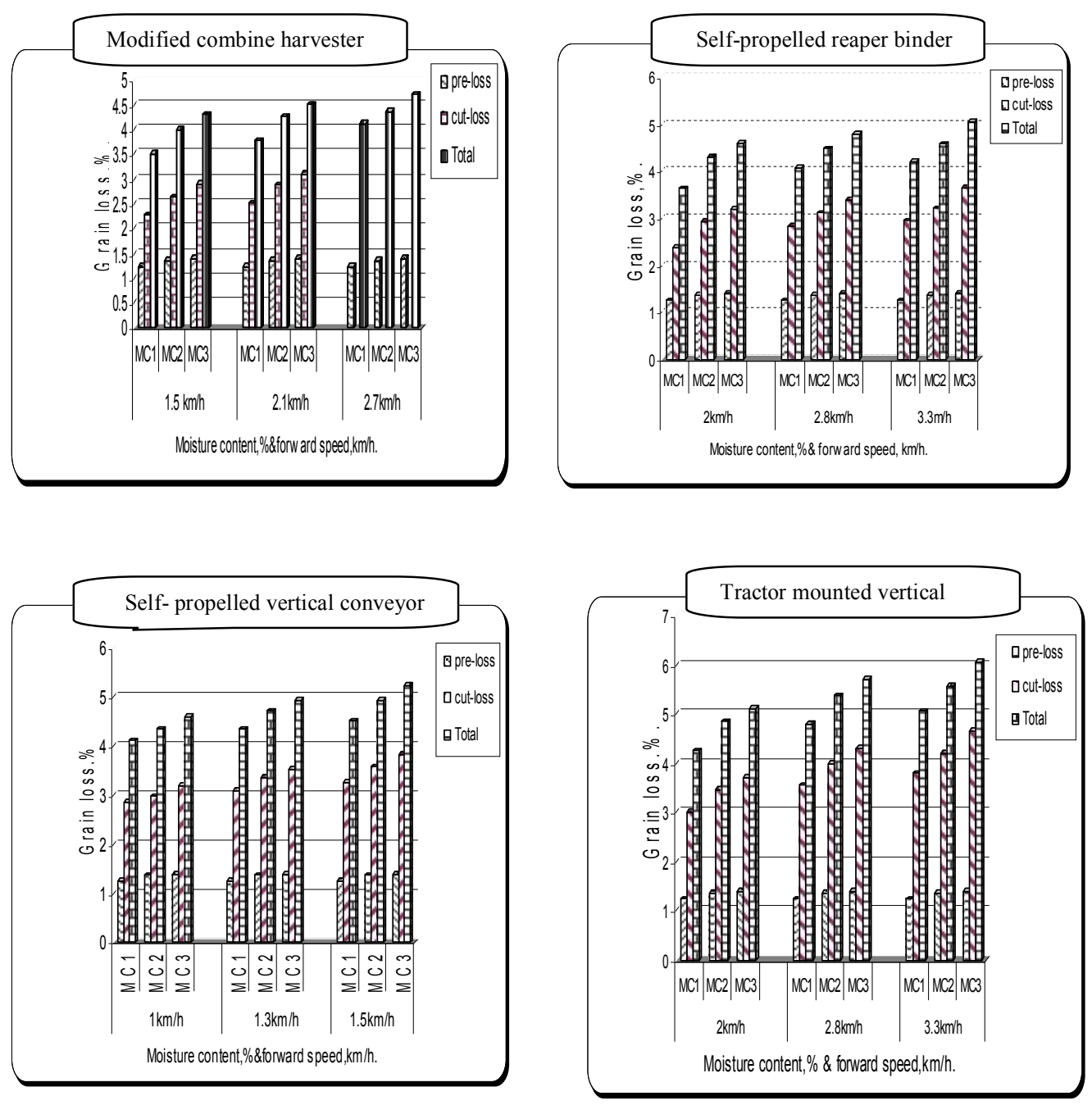

Fig.3. Effect of moisture content and forward speed on grain losses by using mechanical methods.

\section{Effect of crop moisture content and forward speed on cutting efficiency.}

It is clear that the highest value of $97.2 \%$ was noticed under using combine machine with forward speed of $1.5 \mathrm{~km} / \mathrm{h}$ and moisture content of $16.65 \%$. But the maximum value of self-propelled reaper binder was $96.4 \%$ with forward speeds 2.0 $\mathrm{km} / \mathrm{h}$ and moisture content of $16.65 \%$. And the maximum value of traditional harvesting system was $94.0 \%$ with moisture content of $16.65 \%$. While the maximum value of self- propelled vertical conveyor reaper was $93.2 \%$ with forward speed of 1.0 $\mathrm{km} / \mathrm{h}$ and moisture content of $16.65 \%$ and the maximum value of tractor mounted vertical conveyor reaper windrower was $92.4 \%$ with forward speed of $2.0 \mathrm{~km} / \mathrm{h}$ and moisture content of $16.65 \%$. On the whole, it was noticed that the increasing of forward speed tend to decrease the cutting efficiency at different grain moisture contents. This trend may be due to bending of stems under the cutter bar increases by increasing the forward speed. Too, the increasing of moisture content tends to 
increase the cutting efficiency at different forward speeds. These data and another data were showing in Fig.4.

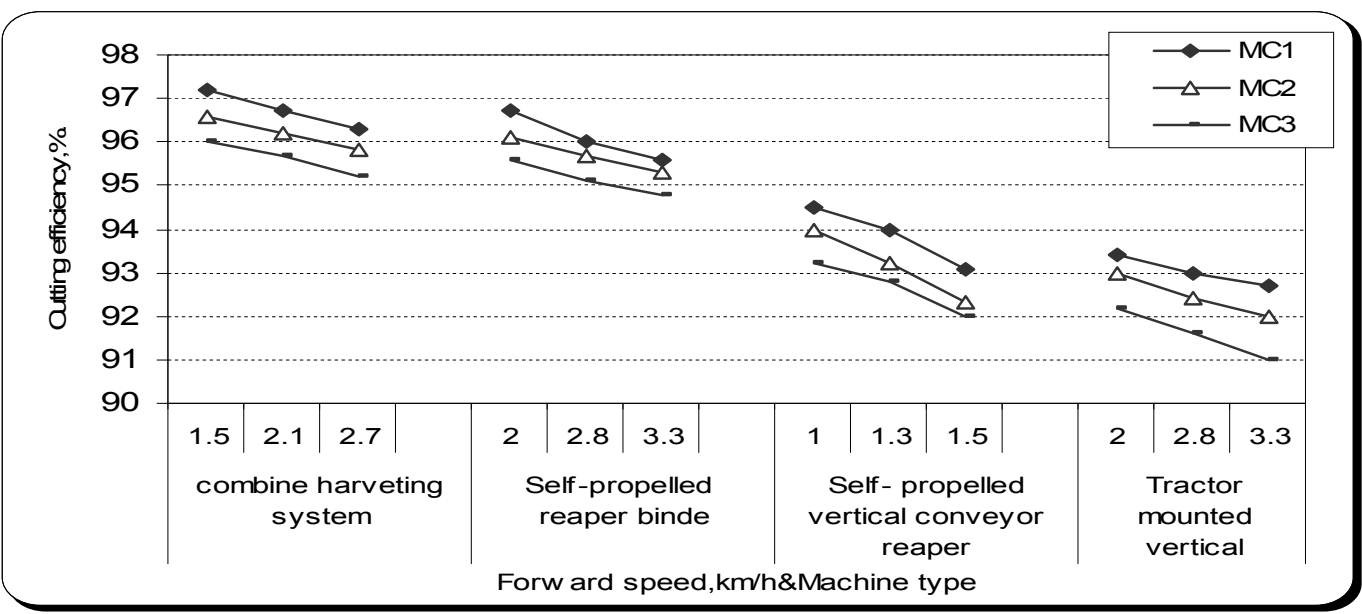

Fig.4. Effect of moisture content and forward speed on cutting efficiency by mechanical method.

\section{Effect of harvesting method on field capacity and efficiency:}

The field capacity and efficiency are very important parameters, which should be taking into consideration when evaluated machine performance. The actual field capacity is affected by many factors such as effective machine width, machine forward speed, cutter bar velocity and grain moisture content. The effect of machine forward speed on actual field capacity was shown in Fig. 5. By increasing forward speed of combine harvester from 1.5 to 2.1 to $2.7 \mathrm{~km} / \mathrm{h}$ the actual field capacity was increased by average from 0.50 to 0.66 to $0.82 \mathrm{fed} / \mathrm{h}$ and decrease field efficiency by average from 84.50 to 81.93 , and $79.23 \%$ at different grain moisture contents of $20.80,18.50$ and $16.65 \%$, respectively. On the other side, by increasing forward speed for self-propelled reaper binder from 2.0 to 2.8 to $3.3 \mathrm{~km} / \mathrm{h}$ increased actual field capacity by average from 0.46 to 0.62 to $0.73 \mathrm{fed} / \mathrm{h}$ and decrease in field efficiency by average from 85.13 to 82.30 , and $79.64 \%$ at different grain moisture contents of $20.80,18.50$ and $16.65 \%$, respectively. Whereas, the increase in forward speed for self- propelled vertical conveyor reaper from 1.0 to 1.3 to $1.5 \mathrm{~km} / \mathrm{h}$ due to increase in actual field capacity by average from 0.19 to $0.26,0.32 \mathrm{fed} / \mathrm{h}$ and decrease field efficiency by average from 86.14 to 82.87 , and $80.00 \%$, at different grain moisture contents of $20.80,18.50$ and $16.65 \%$, respectively. Too, the increase forward speed for tractor mounted vertical conveyor reaper windrower from 2.0 to 2.8 to $3.3 \mathrm{~km} / \mathrm{h}$ increased actual field capacity by average from 0.60 to $0.85,1.05 \mathrm{fed} / \mathrm{h}$ 
and decreased field efficiency by average from 81.64 to 77.73 , and $74.68 \%$, at different grain moisture contents of $20.80,18.50$ and $16.65 \%$, respectively.

\section{Effect of machine forward speed on consumed energy:}

On the whole, it is observed that by increasing forward speed, the consumed energy will decrease. The maximum energies consumed were obtained by using modified combine harvester 17.86, 15.23, and $14.11 \mathrm{~kW} . \mathrm{h} /$ fed at the lower forward speed of $1.5 \mathrm{~km} / \mathrm{h}$ under different grain moisture contents of $20.80,18.50$ and 16.65 $\%$, respectively. While the minimum energies consumed was obtain by using selfpropelled vertical conveyor reaper 9.04, 8.34, and $7.01 \mathrm{~kW} . \mathrm{h} / \mathrm{fed}$ at the highest forward speed of $1.5 \mathrm{~km} / \mathrm{h}$ under different grain moisture contents of 20.80, 18.50 and $16.65 \%$ respectively. Increase forward speed of modified combine from 1.5 to 2.1 to $2.7 \mathrm{~km} / \mathrm{h}$ increased actual field capacity by average from 0.46 to 0.66 to $0.82 \mathrm{fed} / \mathrm{h}$ and decrease field efficiency by average from 84.50 to 81.93 , and 79.23 at different grain moisture contents of $20.80,18.50$ and $16.65 \%$, respectively. But for other machines, tractor mounted vertical conveyor reaper came in second stage by maximum value of $13.46 \mathrm{~kW} . \mathrm{h} / \mathrm{fed}$ at forward speed $2 \mathrm{~km} / \mathrm{h}$ and minimum value of $11.05 \mathrm{~kW} . \mathrm{h} /$ fed at forward speed of $3.3 \mathrm{~km} / \mathrm{h}$, self-propelled reaper binder came in third stage by maximum value of $10.8 \mathrm{~kW} . \mathrm{h} /$ fed at forward speed of $2 \mathrm{~km} / \mathrm{h}$ and minimum value of $8.21 \mathrm{~kW} . \mathrm{h} /$ fed at forward speed of $3.3 \mathrm{~km} / \mathrm{h}$. These data were shown in Fig. 6.

\section{Effect of harvesting machine on cost requiems:}

The total cost for harvesting wheat crop depends on some variables such as, machine price, engine power, specific fuel consumption, fuel price and yearly working hours. The effect of machine forward speed on cost requirements under different grain moisture contents is shown in Fig.7. The minimum total cost requirements values were obtained by using self-propelled reaper binder of 17.17, 15.2014 .00 , L.E/fed at the higher forward speed of $3.3 \mathrm{~km} / \mathrm{h}$ under different grain moisture contents of $20.80,18.50$ and $16.65 \%$, respectively. While the maximum cost requirements values were obtained by using modified combine of 73.96, 72.8 and $70.71 \mathrm{~L} . \mathrm{E} / \mathrm{fed}$ at the lower forward speed of $1.5 \mathrm{~km} / \mathrm{h}$ under different grain moisture contents of $20.80,18.50$ and $16.65 \%$, respectively. But for the other machines, tractor mounted vertical conveyor reaper came in second stage by maximum value of $38.68 \mathrm{~L} . \mathrm{E} / \mathrm{fed}$ at forward speed of $2 \mathrm{~km} / \mathrm{h}$ and minimum value of $20.04 \mathrm{~L}$.E/fed at forward speed of $3.3 \mathrm{~km} / \mathrm{h}$, and self-propelled reaper binder came in third stage by maximum value of $29.33 \mathrm{~L}$.E/fed at forward speed of $2 \mathrm{~km} / \mathrm{h}$ and minimum value of $14.20 \mathrm{~L} . \mathrm{E} / \mathrm{fed}$ at forward speed of $3.3 \mathrm{~km} / \mathrm{h}$. 

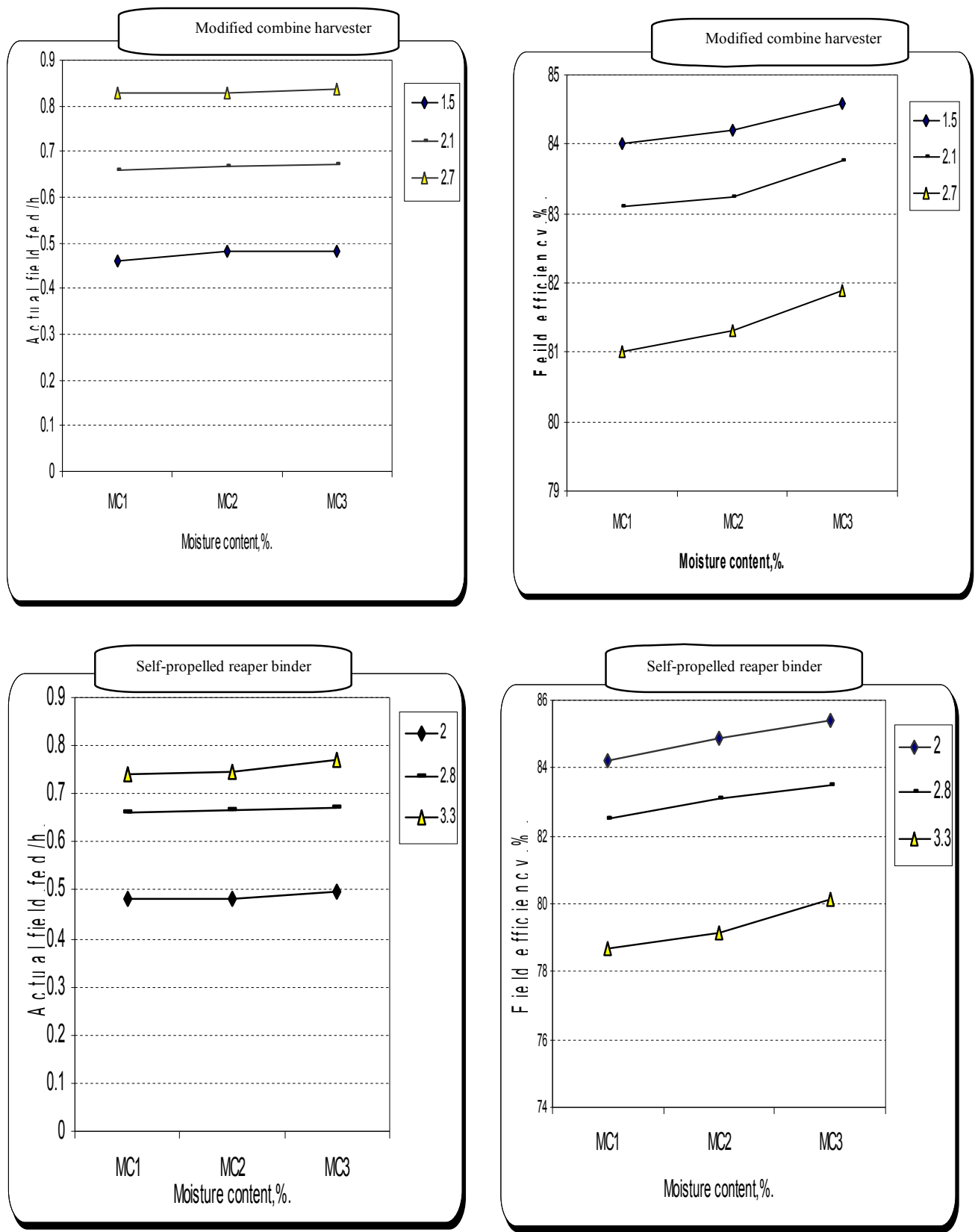

Fig.5. Effect on moisture content on field capacity. 

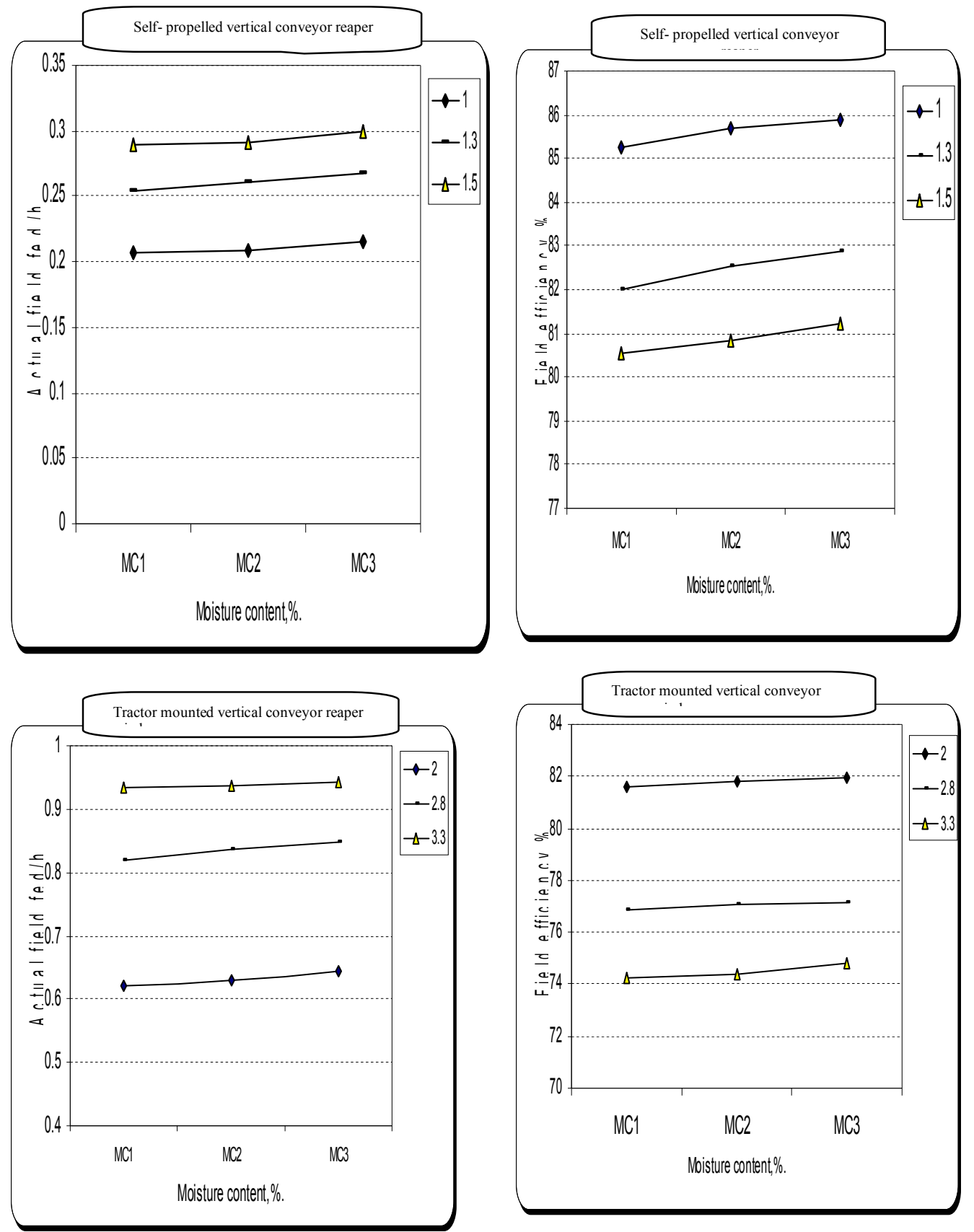

Fig.6. Effect of harvesting machine on field capacity and efficiency 

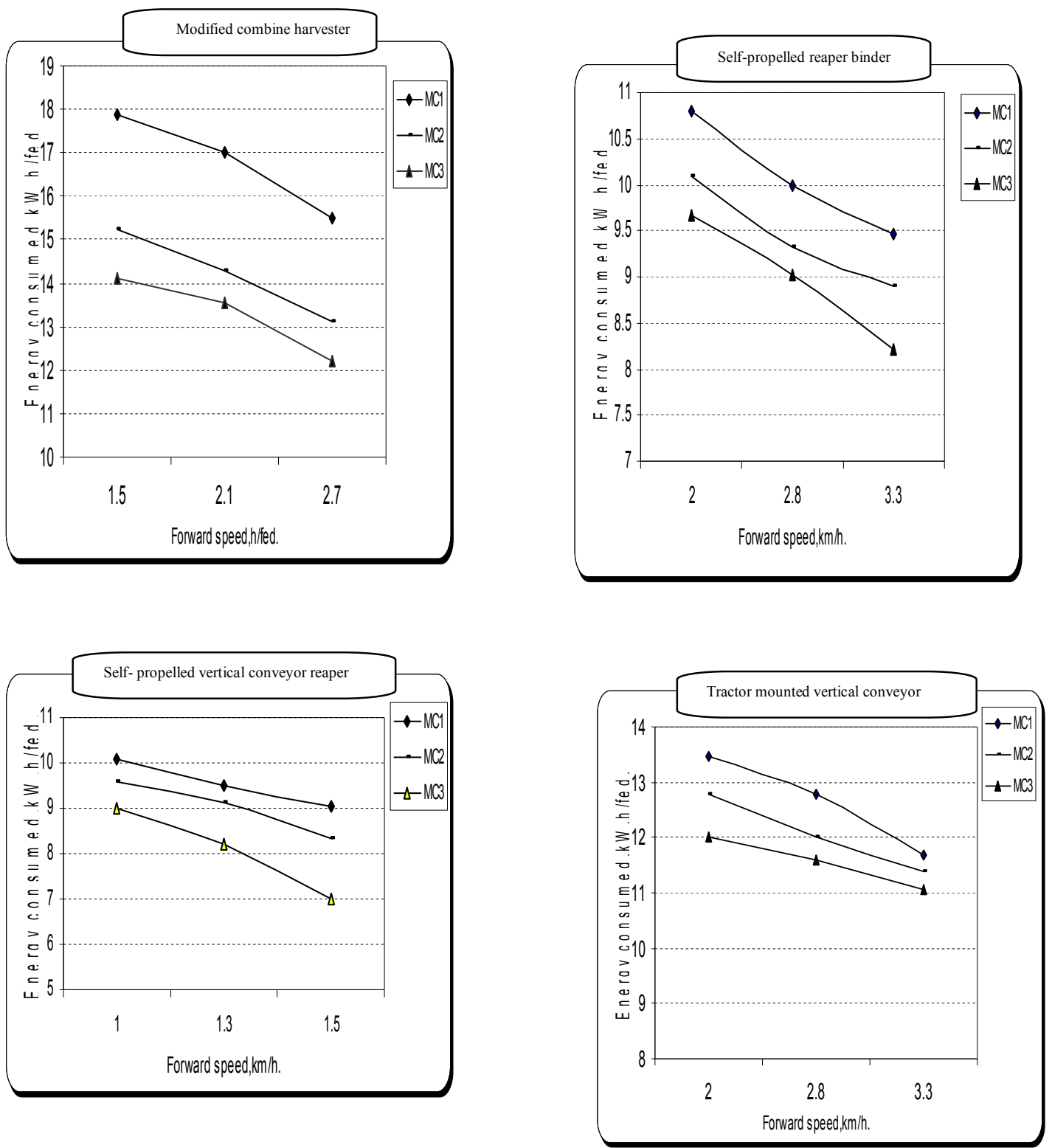

Fig.7. Effect of machine forward speed on consumed energy. 

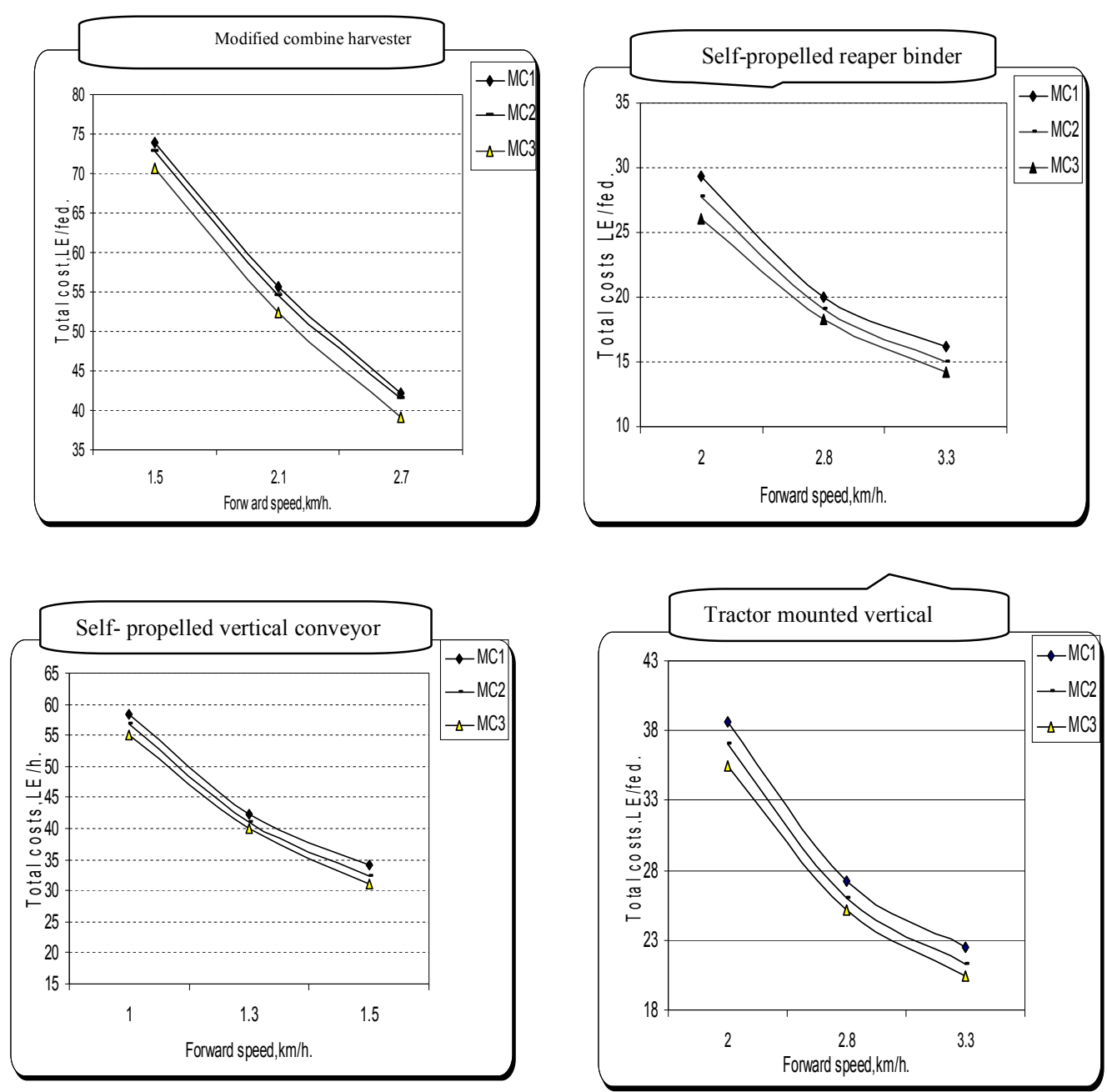

Fig.8. Effect of harvesting machine on cost requirements.

\section{Statistical analysis:}

The major results in statistical analysis appeared that the high significant and significant were obtained under using moisture contents of 16.65 and $18.50 \%$, with first and second speeds with high cut. Also, statistical analysis appeared that the high significant and significant were obtain under using moisture contents of 20.80 and $18.50 \%$, with first and second speeds. So, the high speeds and high moisture contents of seed were not recommended for harvest wheat by these machines. These data were shown in Table 4. 
Table 4. ANOVA analysis.

\begin{tabular}{|c|c|c|c|c|c|c|c|c|c|c|c|c|c|}
\hline \multirow{2}{*}{ 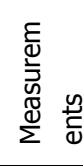 } & \multirow[b]{2}{*}{ t. } & \multicolumn{3}{|c|}{$\begin{array}{l}\text { Combine harvester } \\
\text { modification }\end{array}$} & \multicolumn{3}{|c|}{$\begin{array}{l}\text { Self-propelled } \\
\text { reaper binder }\end{array}$} & \multicolumn{3}{|c|}{ 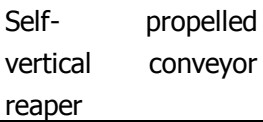 } & \multicolumn{3}{|c|}{$\begin{array}{l}\text { Tractor mounted } \\
\text { vertical conveyor } \\
\text { reaper windrower }\end{array}$} \\
\hline & & $M C_{1}$ & $\mathrm{MC}_{2}$ & $\mathrm{MC}_{3}$ & $M C_{1}$ & $\mathrm{MC}_{2}$ & $\mathrm{MC}_{3}$ & $M C_{1}$ & $\mathrm{MC}_{2}$ & $\mathrm{MC}_{3}$ & $M C_{1}$ & $\mathrm{MC}_{2}$ & $\mathrm{MC}_{3}$ \\
\hline \multirow{3}{*}{ 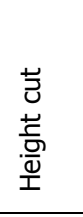 } & $\mathrm{S}_{1}$ & $*$ & $* *$ & $* *$ & ns & * & $* *$ & ns & $* *$ & $* *$ & ns & $*$ & $* *$ \\
\hline & $\begin{array}{l}\mathrm{S} \\
2\end{array}$ & ns & $* *$ & $* *$ & ns & $*$ & $*$ & ns & $*$ & $* *$ & $\mathrm{~ns}$ & $*$ & $* *$ \\
\hline & $\begin{array}{l}\mathrm{S} \\
3\end{array}$ & $\mathrm{~ns}$ & ns & $*$ & ns & $*$ & $*$ & $\mathrm{~ns}$ & ns & $*$ & $\mathrm{~ns}$ & ns & ns \\
\hline \multirow{3}{*}{$\begin{array}{l}\text { Seed } \\
\text { loss }\end{array}$} & $\mathrm{S}_{1}$ & $* *$ & $* *$ & $* *$ & $* *$ & $*$ & $*$ & $* *$ & $* *$ & $* *$ & $* *$ & $* *$ & $*$ \\
\hline & $\mathrm{S}_{2}$ & $*$ & $*$ & $\mathrm{~ns}$ & $* *$ & $* *$ & ns & $* *$ & $* *$ & $* *$ & $*$ & $*$ & ns \\
\hline & $\mathrm{S}_{3}$ & $*$ & ns & ns & $* *$ & ns & ns & $*$ & $*$ & ns & $*$ & ns & ns \\
\hline
\end{tabular}

$\mathrm{S}=$ Forward speed $, \mathrm{km} / \mathrm{h}, \quad \mathrm{MC}=$ moisture content $\left(\mathrm{MC}_{1}=20.80, \mathrm{MC}_{2}=18.50\right.$ and $\left.\mathrm{MC}_{3}=16.65 \%\right)$

** = highly significant at a level of $1 \% \quad *$ = significant at a level of $1 \%$, ns=non significant

\section{CONCLUSION}

In this study, five harvesting systems were evaluated in wheat fields at three average grain moisture contents of $\left(\mathrm{MC}_{1}=20.80, \mathrm{MC}_{2}=18.50\right.$ and $\left.\mathrm{MC}_{3}=16.65 \%\right)$ namely:

1- Traditional harvesting (Hand cutting).

2- Partial mechanization (modified combine harvester, self-propelled reaper binder, self- propelled vertical conveyor reaper and tractor mounted vertical conveyor reaper windrower). Data from this study led to the following conclusions:-

The highest value was $3.2 \%$ at moisture content $16.65 \%$, and the lowest value was $2.4 \%$ at moisture content $20.80 \%$. Add to that the maximum value of total grain losses by using modified combine harvester, self-propelled reaper binder, selfpropelled vertical conveyor reaper and tractor mounted vertical conveyor reaper windrower were about $4.72,5.05,5.24$ and $6.12 \%$ under moisture content of 16.65 $\%$, and forward speeds of $2.7,3.3,1.5$ and $3.3 \mathrm{~km} / \mathrm{h}$ respectively.

The highest value of cutting efficiency of $97.2 \%$ was noticed under the use of By increasing forward speed of combine harvester from 1.5 to 2.1 to $2.7 \mathrm{~km} / \mathrm{h}$ the actual field capacity was increased by average from 0.50 to 0.66 to $0.82 \mathrm{fed} / \mathrm{h}$ and decrease field efficiency by average from 84.50 to 81.93 , and $79.23 \%$ at different grain moisture contents of $20.80,18.50$ and $16.65 \%$, respectively. On the whole by increasing forward speed of harvest machine the actual field capacity was increase and decreased field efficiency. Too, by increasing forward speed the consumed energy will decrease. The minimum cost requirements value was obtained by using selfpropelled reaper binder of 17.17, $15.2014 .00, \mathrm{~L} . \mathrm{E} / \mathrm{fed}$ at the higher forward speed of $3.3 \mathrm{~km} / \mathrm{h}$ under different grain moisture contents of $20.80,18.50$ and $16.65 \%$, respectively. While the maximum total cost requirements value was obtained by using 
modified combine of 73.96, 72.8 and $70.71 \mathrm{L.E} /$ fed at the lower forward speed of $1.5 \mathrm{~km} / \mathrm{h}$ under different grain moisture contents of $20.80,18.50$ and $16.65 \%$, respectively.

-From this study, data obtained recommended to use modified combine harvester, self-propelled reaper binder, self- propelled vertical conveyor reaper and tractor mounted vertical conveyor reaper windrower with medium speed and low grain moisture content, to minimize both consumed energy and cost requirements.

\section{REFERENCES}

1. Abdel El-Aal , A-E , S.E- Badr, and A- lofty. 2002.Consumed energy for transplanting of some vegetable, Misr. J. Ag. Eng., 19(3) 657-667.

2. Awady, M. N. 1978. Engineering of tractors and agricultural machinery.Text Book, Col. Ag. Ain-shams Univ., 5th. Ed: 161-164. In Arabic.

3. Awady, M. N, E. Y. Ghoneim and A. I. Hashish. 1982. A critical comparison between wheat combine harvesters under Egyptian conditions. R. S. No. 1920, Ain-Shams Univ. (FAO). J.

4. Abo EL-Naga, M.H.M., M.A. Shetawy. and Sh.F Abed El-Hammed,2010. Evaluating the performance of a locally combine for harvest wheat crop. Misr J. Ag. Eng. 27 (1): $104-121$.

5. El-Haddad, Z. A, M. Y. El-Anssary and S. A. Aly. 1995. Cost benefit study under integrated mechanization systems. Misr J.Agr. Eng., 12 (1): 27-35.

6. EL-Sayed G. H., M. A. EL-Ataar and E. M. Arif. 2002. Mechanical harvesting of sun flower using the general purpose combines. The 10 annual conference of the Misr of Ag. Eng, 16-17:155-172.

7. El-Yamani, A.E. 2013. Development of combine harvesting for decreasing Egyptian clover seed losses. International Conference of Agricultural \& Bio-Engineering Egyptian Ag.Res. (2):481-500.

8. Fouad, H. A, S. A. Tayel, Z.A. El-Hadad and H. A.Abdel-Mawla.1990. Performance of two different types of combine inharvesting rice crop in Egypt. AMA. 21 (3): $17-22$.

9. Hunt, D. ,1983."Farm power and machinery management. Iowa state Univ. Press, Ames, Lowa U. S. A.

10. Hassan, M. A, M. M. Morad, M. A. El-Shazly and A. Farag. 1994. Study on some operating parameters affecting the performance of combine devices with reference to grain losses.Misr J. Agr. Eng., 11 (3): 764-780.

11. Imara Z. M.,Kh. A. A. Khadr, W. M. Mechail and A. O. M. Arif. 2003. Effect of different planting and harvesting methods on wheat production. Misr J. Agr. Eng. 20(1): 115-128. 


\section{مقارنة بين أكثر الطرق الآلية شيوعا وكومبين الارز

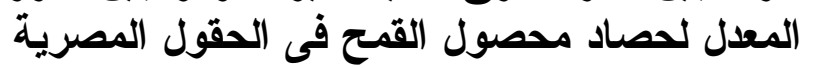

\section{شرين فؤاد عبدالحميد محمد - محد الثحات بدوى - محمد حمة مخيمر أبو النجا}

$$
\text { معهُ بحوث الهنسة الزراعية - مركز البحوث الزراعية - الدقى - الجيزة - مصر }
$$

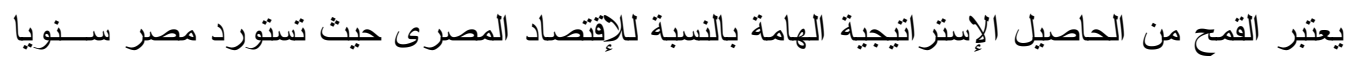

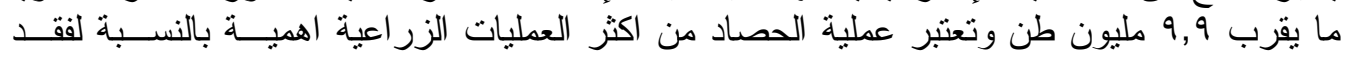

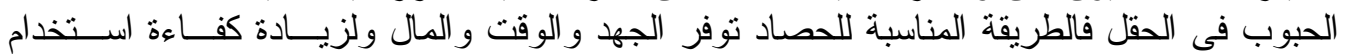

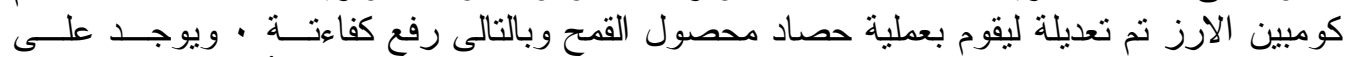

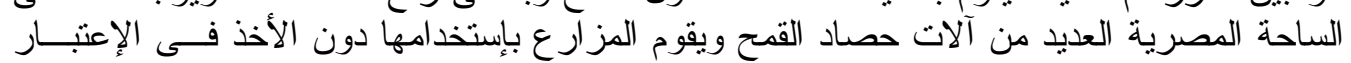

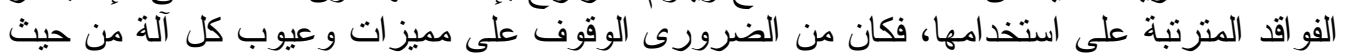

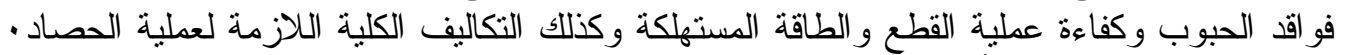

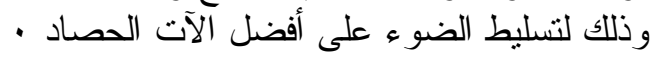

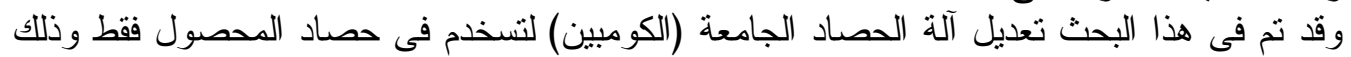

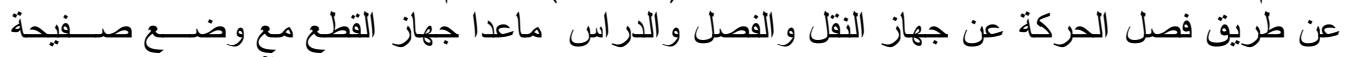

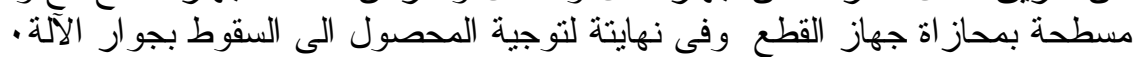

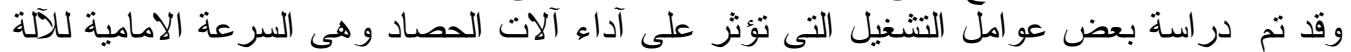

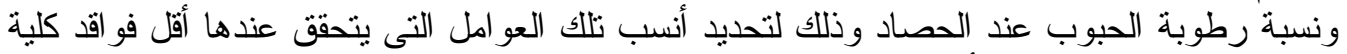

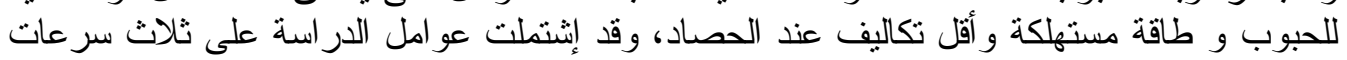

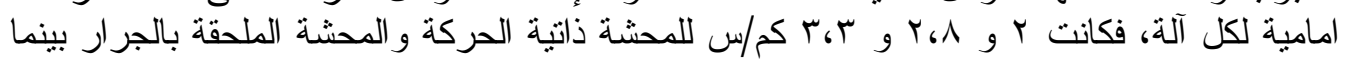
كانت للكو مبين

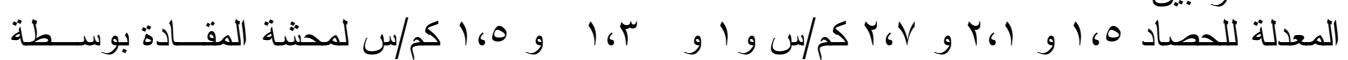
• الإنسان

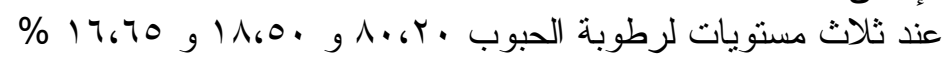

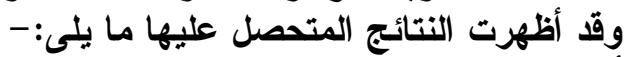

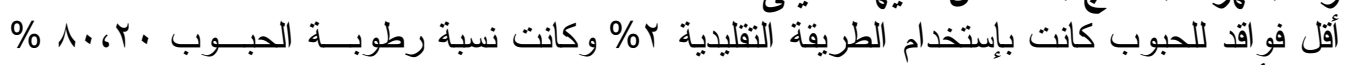

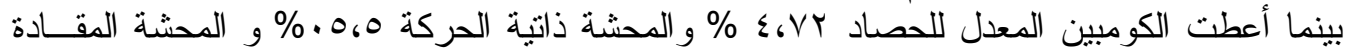

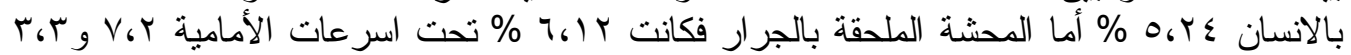

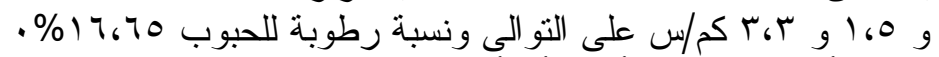

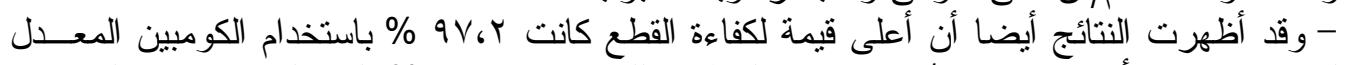

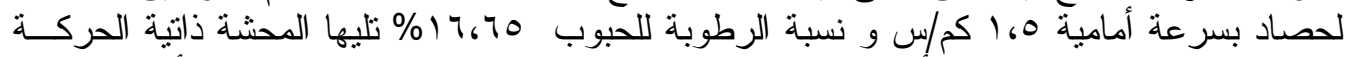

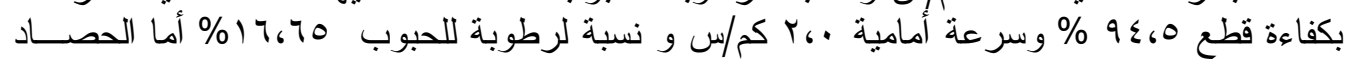

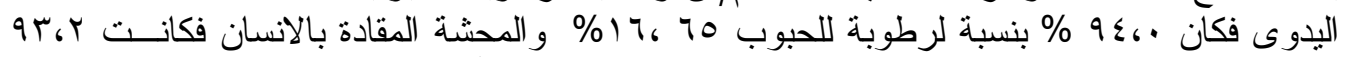

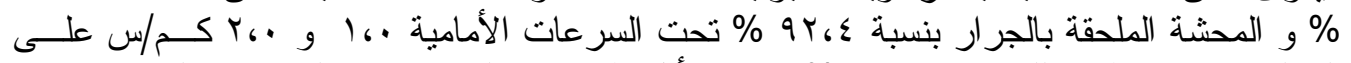

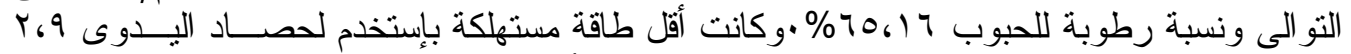

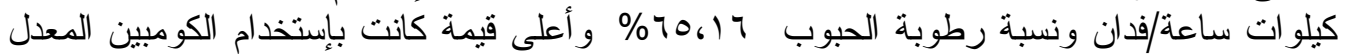

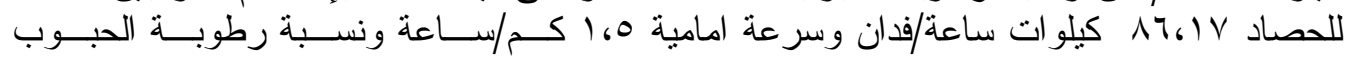

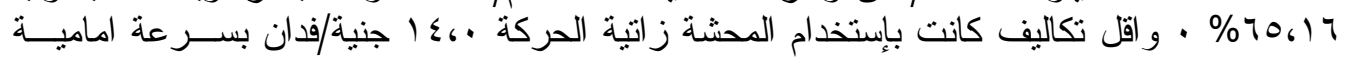

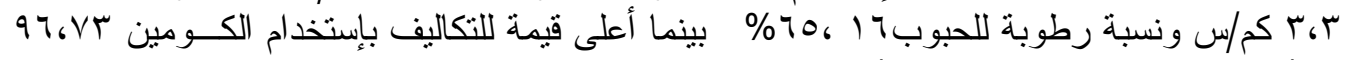

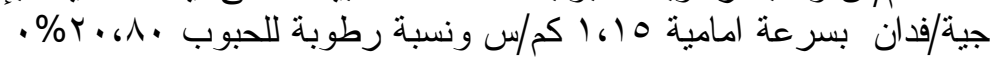

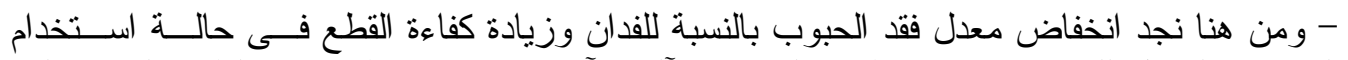

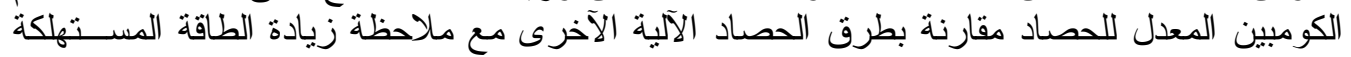
و التكاليف بالنسبة للفدان • لإن 